\title{
First Records of the Northern Long-eared Bat, Myotis septentrionalis, in the Yukon Territory
}

\author{
Thomas S. Jung ${ }^{1}$, Brian G. Slough ${ }^{2}$, David W. Nagorsen ${ }^{3}$, Tanya A. Dewey ${ }^{4}$, and Todd Powell ${ }^{1}$ \\ ${ }^{1}$ Yukon Department of Environment, Fish and Wildlife Branch, Box 2703, Whitehorse, Yukon Territory Y1A 2C6 Canada; \\ e-mail: thomas.jung@gov.yk.ca \\ 235 Cronkhite Road, Whitehorse, Yukon Y1A 5S9 Canada \\ ${ }^{3}$ Mammalia Biological Consulting, 4268 Metchosin Road, Victoria, British Columbia V9C 3Z4 Canada \\ ${ }^{4}$ Mammal Division, Museum of Zoology, University of Michigan, 1109 Geddes Road, Ann Arbor, Michigan 48109-1079 \\ U.S.A.
}

Jung, Thomas S., Brian G. Slough, David W. Nagorsen, Tanya A. Dewey, and Todd Powell. 2006. First record of the Northern Long-eared Bat, Myotis septentrionalis, in the Yukon Territory. Canadian Field-Naturalist 120(1): 39-42.

Three adult male Northern Long-eared Bats, Myotis septentrionalis, were captured in mist nets in July 2004 in the LaBiche River Valley, southeastern Yukon. These are the first records of M. septentrionalis in the Yukon. Further survey work is needed to delineate the extent of the range and population structure of this and other species of bats in northwestern North America.

Key Words: Northern Long-eared Bat, Myotis septentrionalis, distribution, Yukon.

The diversity and distribution of bats in northwestern North America (e.g., $\geq 55^{\circ} \mathrm{N}$ ) is poorly documented. Few areas have been adequately surveyed, particularly for rare or cryptic species (sensu Nagorsen and Brigham 1993; van Zyll de Jong and Nagorsen 1994; Parker and Cook 1996; Parker et al. 1997). Youngman (1975) reported the Little Brown Bat (Myotis lucifu$g u s)$ as the only species of bat in the Yukon. However, Youngman (1975) noted the possibility of other species occurring in the Yukon, such as the Big Brown Bat (Eptesicus fuscus) and Long-legged Bat (Myotis volans), based on single specimens collected near Fairbanks, Alaska, and Atlin, British Columbia, respectively. In the 30 years subsequent to Youngman (1975), no species of bats other than M. lucifugus have been confirmed from the Yukon. Slough (2000*), however, recorded a bat in southeastern Yukon that appeared to be a Big Brown Bat according to its echolocation call characteristics (C. Corben, personal communication), but it may have been a Silver-haired Bat (Lasionycteris noctivagans) and remains to be verified by a capture. We believe that species other than M. lucifugus may extend northward into the Yukon, and that a lack of records of other species is largely a function of previous search effort.

Based on a specimen collected in Nahanni National Park, Northwest Territories (van Zyll de Jong 1985), captures in recent surveys in adjacent British Columbia (Wilkinson et al. 1995*; Vonhof and Wilkinson 1997*), and an unidentified Myotis in a recording of an echolocation call (Slough 2000*), we suspected that the Northern Long-eared Bat (Myotis septentrionalis) and the Western Long-eared Bat (Myotis evotis) could be present in southeastern Yukon. In summer 2004, we undertook a preliminary field survey of the mammalian diversity in the boreal forest of southeastern Yukon, including a bat inventory. Here, we provide the first records of the Northern Long-eared Bat in the Yukon.

\section{Methods}

On 28 July - 2 August 2004, we used mist-nets to capture bats in the LaBiche River Valley $\left(60.126^{\circ} \mathrm{N}\right.$, $124.064^{\circ} \mathrm{W}$ ) of extreme southeastern Yukon. Mist-netting occurred at three sites; two sites were over small ponds $\left(>150 \mathrm{~m}^{2}\right)$ within dense boreal forest, and another at an intersection of a roughly $3 \mathrm{~m}$ wide forest trail and a roughly $30 \mathrm{~m}$ wide forest access road. Nets were set across and bordering the ponds and perpendicular to the road and forest trail. Nets were opened $0.5 \mathrm{hr}$ before sunset (about 23:00 hrs PDT) and closed 2-3 hr thereafter. A $6 \mathrm{~m}$ long mist net open for $1 \mathrm{hr}$ was used as our definition of 1 mist-net hr.

Captured bats were examined for external diagnostic characteristics according to van Zyll de Jong (1985) and Nagorsen (2002), including presence of dark shoulder patches in the pelage, ear length, number of hairs on the trailing edge of the uropatagium, presence of keeled calcar, and relative length and shape of the tragus. We measured forearm length, ear length, and mass, and determined age as per van Zyll de Jong (1985). No voucher specimens were procured; rather, we obtained morphological measurements and wing punches for mitochondrial DNA sequencing to verify our field identifications. Wing punches were stored in $70 \%$ ethanol until lab analysis. Genetic analyses were conducted at the University of Michigan's Museum of Zoology (Ann Arbor, Michigan), and included an unweighted maximum parsimony analysis of $745 \mathrm{bp}$ of the cytochrome $b$ gene using 21 specimens of Myotis (Figure 1). 


\section{Results and Discussion}

We amassed 42.1 mist-net hr over six nights of sampling; only six bats were captured. On 28 July 2004, we captured two adult male $M$. septentrionalis and one $M$. lucifugus at a small, shallow pond (ca. $\left.108 \mathrm{~m}^{2}\right)$. On 29 July 2004, a third adult male northern M. septentrionalis and two M. lucifugus were captured at the same pond. Although three of our captures were consistent with the morphological traits of $M$. septentrionalis (Table 1), this species can be difficult to distinguish from other species of potentially sympatric long-eared Myotis (i.e., M. evotis and M. keenii), based on external characteristics alone (van Zyll de Jong 1979; Nagorsen 2002). DNA sequences, however, confirmed our tentative species identifications: the three M. septentrionalis are included in the M. septentrionalis clade (Figure 1).

The presence of $M$. septentrionalis in the Yukon is not surprising, considering that captures were reported from elsewhere in the Liard River Watershed by Wilkinson et al. (1995*), Bradbury et al. (1997*) and Vonhof and Wilkinson (1997*). The only voucher taken in those surveys to confirm identification, however, was a specimen of $M$. septentrionalis collected by Vonhof and Wilkinson $\left(1997^{*}\right.$ ) from the Fort Nelson River, British Columbia, near Highway 77 (Royal British Columbia Museum, RBCM 19516), about 140 km southeast of our captures. It is not known if there are breeding populations of M. septentrionalis in the Yukon, as no juveniles, or lactating or post-lactating females were captured. Breeding populations of the Northern Long-eared Bat, however, have been reported from nearby northeastern British Columbia (Wilkinson et al. 1995*, Vonhof and Wikinson 1997*). Similarly, it is not known if $M$. septentrionalis hibernates in the Yukon. No bat hibernacula have been found in the Yukon.

Despite low capture rates, we suspect that M. septentrionalis were locally common in our survey area, based on the number of captures relative to M. lucifugus. Moreover, we often detected what appeared to be M. septentrionalis at all of the mist-netting sites, based on low intensity echolocation calls (Faure et al. 1993) heard on narrowband bat detectors tuned to $40-50 \mathrm{kHz}$ and observations of detection distances of passing bats. Our data, along with that of Wilkinson et al. (1995*), Bradbury et al. (1997*), and Vonhof and Wilkinson
(1997*), suggest that M. septentrionalis may be locally common and widely distributed throughout the Liard River Watershed in British Columbia and the Yukon. We suspect that M. septentrionalis may occur throughout the Liard River Watershed in the Yukon, from the LaBiche River west to the Little Rancheria River. Other species of bats (e.g., M. evotis, M. volans, Eptesicus fuscus, and Lasionycteris noctivagans) may also be present in southern Yukon, but not yet confirmed with a capture, voucher, or DNA sample.

Perhaps the most intriguing question is whether $M$. septentrionalis is a long-established member of the Yukon mammalian fauna that has simply gone undetected, or, alternatively, is it a species that has recently (i.e. $<100$ years ago) colonized southeastern Yukon? Other mammals have recently colonized the Yukon, from the south, including: Mule Deer and White-tailed Deer (Odocoileus hemionus and O. virginianus; Hoefs 2001), Coyote (Canis latrans; Youngman 1975), and Cougar (Puma concolor; Jung et al. 2005). Moreover, Humphries et al. (2002) provided data from simulation models that suggested that the range of M. lucifugus, and presumably other species of bats in the boreal forest, would substantially move northward in response to global warming. Regardless of the origin of M. septentrionalis in the Yukon, these records underscore that our knowledge of the diversity and distribution, and population structure of bats in the Yukon is limited. Directed surveys are needed to address these information gaps and provide a basis for management and conservation initiatives that include bats.

\section{Acknowledgments}

S. Cannings and A. Runck kindly provided comments on an earlier draft of this note. Additional tissue samples for DNA sequence comparison were kindly provided by T. Dewey, P. Myers, D. Burles, and R. Benedict. The staff of Devon Canada Corporation's LaBiche River Gas Plant kindly went out of their way to accommodate us and provide logistical support. Funding was provided by the Yukon Department of Environment and NatureServe Yukon. Additional financial support was provided by a Northern Research Endowment Grant from the Northern Research Institute, Yukon College, to B. Slough.

TABLE 1. Age, sex, and morphometrics of Myotis septentrionalis $(n=3)$ captured in the LaBiche River valley, southeastern Yukon, 28-29 July 2004

\begin{tabular}{|c|c|c|c|c|c|c|c|}
\hline $\begin{array}{l}\text { Specimen } \\
\text { Label }\end{array}$ & $\begin{array}{l}\text { GenBank } \\
\text { Accession }\end{array}$ & Species $^{1}$ & Sex & Age & $\begin{array}{c}\text { Forearm } \\
\text { Length }(\mathrm{mm})\end{array}$ & $\begin{array}{c}\text { Ear } \\
\text { Length }(\mathrm{mm})\end{array}$ & $\begin{array}{l}\text { Mass } \\
(\mathrm{g})\end{array}$ \\
\hline LaBiche-1 & AY883902 & M. septentrionalis & Male & Adult & 16 & 37.7 & 7.6 \\
\hline LaBiche-3 & AY883904 & M. septentrionalis & Male & Adult & 15 & 35.8 & 6.6 \\
\hline LaBiche-9 & AY883905 & M. septentrionalis & Male & Adult & 14 & 37.6 & 6.9 \\
\hline
\end{tabular}

${ }^{1}$ As tentatively identified in the field and subsequently confirmed with genetic analyses. 


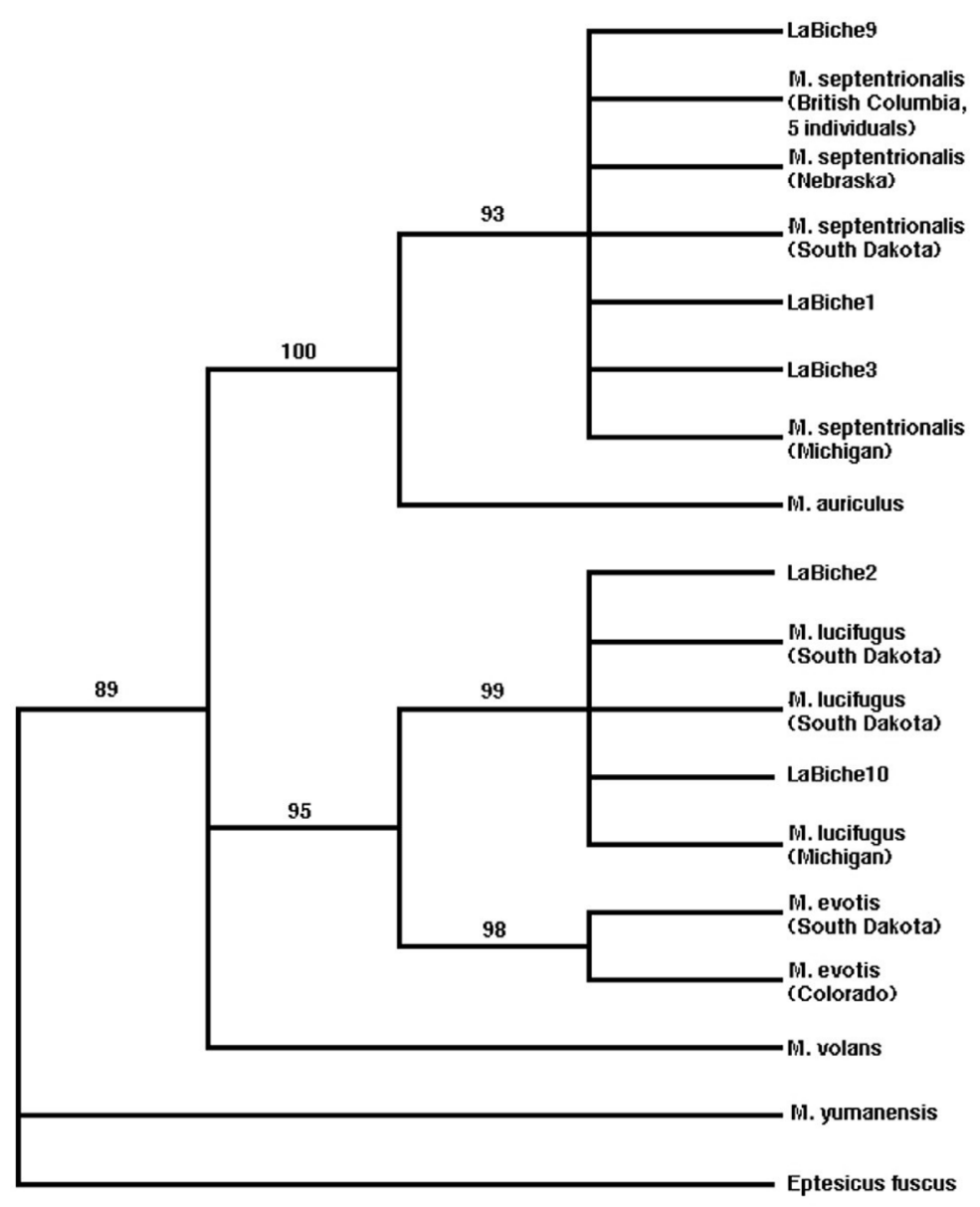

FIGURE 1. Placement of Myotis septentrionalis (LaBiche 1,3, and 9) and M. lucifugus (LaBiche 2 and 10) samples collected in the LaBiche River Valley, Yukon, based on an unweighted maximum parsimony analysis of cytochrome $b$ (745 bp) for these samples compared to other Myotis. Eptesicus fuscus is used as an outgroup. Numbers above the branches represent bootstrap support values for those nodes.

Documents Cited (marked $*$ in the text)

Bradbury, S. M., S. Morris, and S. McNally. 1997. Bat survey of the Liard River watershed in British Columbia. Unpublished Report. British Columbia Ministry of Environment, Lands and Parks, Victoria, British Columbia. 29 pages.

Slough, B. G. 2000. A survey of the bat fauna of the Yukon Territory: 1999 field studies. Unpublished Report. Northern Research Institute, Yukon College, Whitehorse, Yukon. 26 pages.

Vonhof, M. J., and L. C. Wilkinson. 1997. Roosting habitat requirements of northern long-eared bats (Myotis septentrionalis) in the boreal forest of northeastern British Columbia. Unpublished Report. British Columbia Ministry of Environment, Lands and Parks, Fort St. John, British Columbia. 88 pages.

Wilkinson, L. C., P. F. J. Garcia, and R. M. R. Barclay. 1995. Bat survey of the Liard River watershed in northern British Columbia. Unpublished Report. British Columbia
Ministry of Environment, Lands and Parks, Victoria, British Columbia. 39 pages.

\section{Literature Cited}

Faure, P. A., J. H. Fullard, and J. W. Dawson. 1993. The gleaning attacks of the northern long-eared bat, Myotis septentrionalis, are relatively inaudible to moths. Journal of Experimental Biology 178: 173-189.

Hoefs, M. 2001. Mule, Odocoileus hemionus, and Whitetailed, $O$. virginianus, deer in the Yukon. Canadian FieldNaturalist 115: 296-300.

Humphries, M. M., D. W. Thomas, and J. R. Speakman. 2002. Climate-mediated energetic constraints on the distribution of hibernating mammals. Nature 418: 313-316.

Jung, T. S., and P. J. Merchant. 2005. First confirmation of cougar, Puma concolor, in the Yukon. Canadian Field-Naturalist 119(4): 580-581. 
Nagorsen, D. W. 2002. An identification manual to the small mammals of British Columbia. Ministry of Sustainable Resource Management, Ministry of Water, Land and Air Protection, and Royal British Columbia Museum, Victoria, British Columbia. 153 pages.

Nagorsen, D. W., and R. M. Brigham. 1993. Bats of British Columbia. Volume 1. The Mammals of British Columbia. UBC Press, Vancouver, British Columbia. 176 pages.

Parker, D. I., and J. A. Cook. 1996. Keen's long-eared bat, Myotis keenii, confirmed in southeast Alaska. Canadian Field-Naturalist 110: 611-614.

Parker, D. I., B. E. Lawhead, and J. A. Cook. 1997. Distributional limits of bats in Alaska. Arctic 50: 256-265. van Zyll de Jong, C. G. 1979. Distribution and systematic relationships of the long-eared Myotis in western Canada. Canadian Journal of Zoology 57: 987-994.

van Zyll de Jong, C. G. 1985. Handbook of Canadian mammals. Volume 2: Bats. National Museum of Natural Sciences, Ottawa, Ontario. 212 pages.

van Zyll de Jong, C. G., and D. W. Nagorsen. 1994. A review of the distribution and taxonomy of Myotis keenii and Myotis evotis in British Columbia and the adjacent United States. Canadian Journal of Zoology 72: 1069-1078. Youngman, P. M. 1975. Mammals of the Yukon Territory. National Museums of Canada, Ottawa, Ontario. 192 pages.

Received 4 February 2005

Accepted 12 September 2005 